\title{
Development of Methodology to Assess the Effect of Cross-cultural Differences in the Consumer Behavior
}

\author{
Elena Viktorovna Noskova ${ }^{1} \&$ Irina MatveevnaRomanova ${ }^{1}$ \\ ${ }^{1}$ Far Eastern Federal University, Vladivostok, Suhanova Street, 8, Russian Federation \\ Correspondence: Elena Viktorovna Noskova, Far Eastern Federal University, 690950, Vladivostok, \\ SuhanovaStreet, 8, Russian Federation. E-mail: rim.6767@mail.ru
}

Received: August 24, 2014 Accepted: September 10, 2014 Online Published: November 27, 2014

doi:10.5539/ass.v10n24p248 URL: http://dx.doi.org/10.5539/ass.v10n24p248

\begin{abstract}
The article notes that globalization and the development of international trade leads to an increase in the flow of goods, services, and ideas across borders and cultures, as well as reduction of technological barriers that increases the relevance of cross-cultural research. The purpose of this study is to develop methodological tools to assess the effect of cross-cultural differences in the consumer behavior in the fish and seafood market. A cultural model, reflecting a set of cultural values, the characteristics of material environment (level of scientific and technological development and its potential, natural resources, the level of economic development, and the geographical location of the country), the institutional environment (the value of the family as a social institution, the effect of government regulation and the activities of environmental organizations, as well as the level of literacy and education). The study highlighted specific features of a culture-specific model development with due consideration of fish and seafood markets. The results of testing the proposed survey frame are presented through the example of Asia-Pacific (AP) region countries, such as China, Russia and South Korea.
\end{abstract}

Keywords: consumer behavior, cross-cultural factors, cultural model, fish and seafood market

\section{Introduction}

Present-day world is becoming a single space for flow of goods, services, ideas, capital, labor, etc. In the context of globalization, international trade is becoming increasingly important as a factor of the effective development of any national economy. A number of contacts established between people of different cultures, values, beliefs and convictions are increasing progressively that leads to emergence of cross-cultural conflicts. This issue becomes particularly acute when the company enters into the international market. Ethnic cultural characteristics, mentality and habits largely determine consumer behavior in different markets and have different effects on the perception of goods and services in various countries. This confirms the importance of studying and analyzing the cultural features of the different nations, their behavioral norms, traditions and social constraints.

Cross-cultural differences are the subject being studied by biologists, psychologists, ethno-psychologists, cultural specialists, managers, marketing experts and other researchers. Cross-cultural aspects are analyzed in the works of (Aleshina, 2010; Aleshina, 2011; Berry et al., 2007; Kuznetsova \& Leontiev, 2012; Lebedeva, 2010; Matsumoto, 2002; Tatarko, 2012; Agarwaletal, 2010; Dimitrovaetal, 2014; Cheungetal, 2011; Maldaetal, 2010; Moven, 1995; Gesteland, 2012; Gelade, 2008; Harrison, 2006; Rigbymetal, 2009; Hofstedeetal, 2002; Oweetal, 2013; Romanova \& Noskova, 2014). In this article the cross-cultural differences are discussed in the context of the marketing. At the present stage cross-cultural studies are mostly based on the use of empirical techniques. Lack of the cross-functional methodological approach, which would take into account peculiarities of culture in different countries, still is a problem of cross-cultural research. Available techniques do not take into account the sectorial and regional markets specifics. All this circumstances testify the relevance of the current research topic and its insufficient profoundness.

\section{Methodology}

When developing a methodology of cross-cultural research, it is needed to determine the base for comparison of different cultures, to develop research tools and to select data collecting and processing techniques. Analysis of the relevant scientific literature showed that there are a significant number of different techniques to compare cultures. They are all based on the use of quantitative or qualitative methods. In our study, we offer an integrated 
approach that combines both quantitative and qualitative assessment techniques.

At the first stage it is necessary to determine a set of basic parameters for comparing cultures of different countries. For this propose we propose to use a culture matrix (Moven, 1995), tailored to the fish and seafood market. This matrix includes cultural model elements, such as cultural values, and the characteristics of the material and institutional (social) environments. The following value classification was used when designing a system of cultural values: self-focused values (materialism, proactive attitude, efficiency and pragmatism), values focused on other persons (individualism, equality of rights, humanity, youthfulness, and social conformity), and the environment-focused values (traditions and power over nature) (Aleshina, 2010; Matsumoto, 2002).

When studying cross-cultural differences, let attribute the following characteristics to culture elements within the frameworks of material and institutional environments (Aleshina, 2010; Aleshina, 2011; Moven, 1995):

- the material environment includes the level of scientific and technological development and its potential, the amount of natural resources stock, the level of economic development, and the geographical location of the country;

- the institutional environment includes family value as a social institution, the effect of government regulation, the effect of the environmental organizations activities, and the level of literacy and education.

Cultural model is developed based on indicated elements. In order to compare cultural models for different countries, cultural model elements are assessed by experts on Likert scale (Agarwaletal, 2010), where 1 means strongly disagree, 2-disagree, 3-hard to answer, 4-agree, and 5-strongly agree. Then the average scores are calculated for each country, which are used to build radar plots, allowing a visual assessment of the similarities and differences in cultural models of different countries by superposition of their plots.

The results of the consumer survey served primary information sources. The sample volume to conduct survey included 300 respondents. When forming sample frame, we considered age, education, ethnicity and knowledge of Russian language.

The proposed tool to assess cultural models was used for the detection of differences in consumer behavior in the context of fish and seafood market in Asia-Pacific countries, namely China, Russia and South Korea. The analysis was carried out with respect to the following parameters: selection of the fish and seafood type, selection of product depending on the processing type, fish and seafood consumption frequency, the amount of one-time purchase, selection of the point-of-purchase location and format, and the trust to advertising communications.

A comparison of the cultural model elements and consumer behavior patterns was conducted by constructing contingency matrices (Table 1).

Table 1. Estimator matrix to assess the effect of cultural model elements on the fish and seafood consumption patterns in the Asia-Pacific countries (Author's development)

\begin{tabular}{llll}
\hline $\begin{array}{l}\text { Cultural model elements Consumer behavior } \\
\text { patterns (M) }\end{array}$ & $\begin{array}{l}\text { Cultural } \\
\text { values }\end{array}$ & $\begin{array}{l}\text { Material } \\
\text { environment }\end{array}$ & $\begin{array}{l}\text { Institutional } \\
\text { environment }\end{array}$ \\
\hline
\end{tabular}

Selection of the fish and seafood type

Selection of product depending on the processing type

Fish and seafood consumption frequency

Amount of one-time purchase

Selection of the point-of-purchase location and format

Trust to advertising communications

\section{Results}

\subsection{Construction of Cultural Models of Selected Countries in the Asia-Pacific Region}

Questionnaire survey performed was based on the developed technique. It enabled us to determine the most indicative cultural values, inherent in fish and seafood consumers in selected Asia-Pacific countries (China, Russia and South Korea) (Figure 1). 


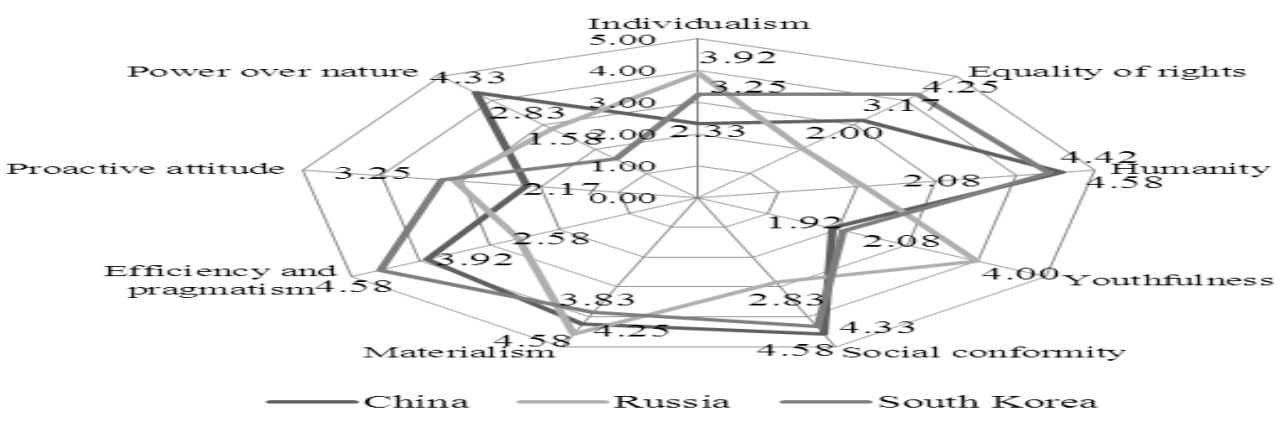

Figure 1. Comparison of cultural values conformity assessment with respect to cultures of selected Asia-Pacific countries, 2014 (Author's development)

The largest gaps in the cultural values assessment are noted with regard to the following characteristics:

1) humanity: this feature corresponds to the fullest extent to the Chinese and South Korean cultures;

2) youthfulness most closely matches the Russian culture;

3) power over nature is characterized by a greater degree to Chinese culture;

4) equal rights to life and liberty are more typical to South Korean culture.

Minor gaps are observed in the assessment of characteristics, such as materialism and proactive attitude. Assessment of material and social environment elements of the concerned countries is shown in Figs. 2 and 3.

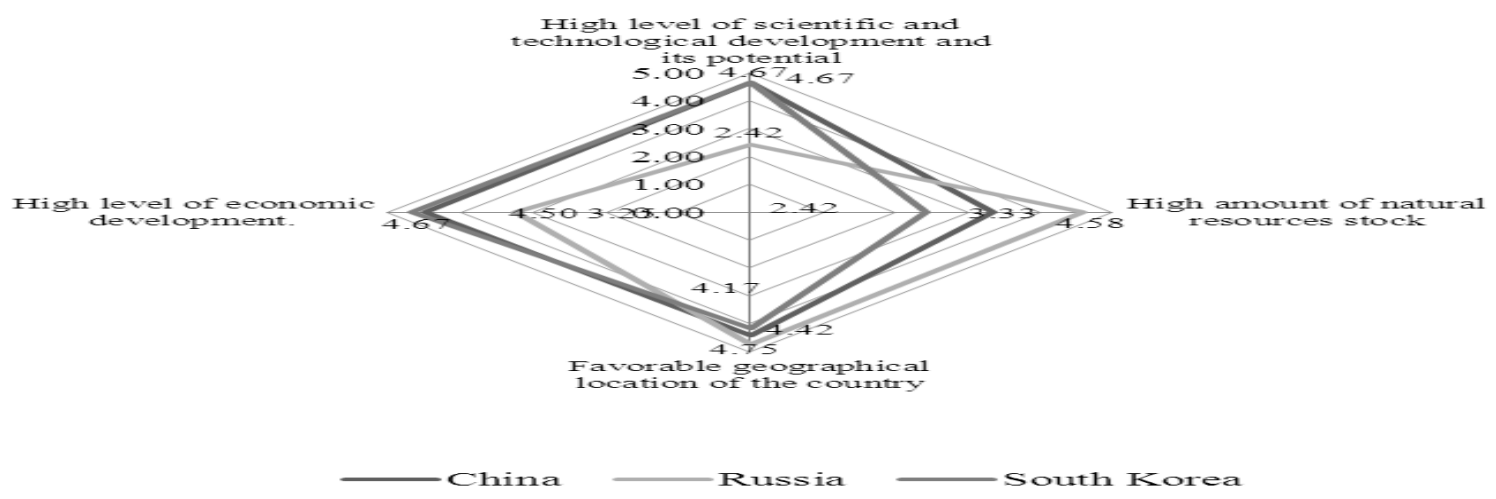

Figure 2. Comparison of conformity assessment for the material environment components with respect to cultures of the Asia-Pacific countries, 2014 (Author's development)

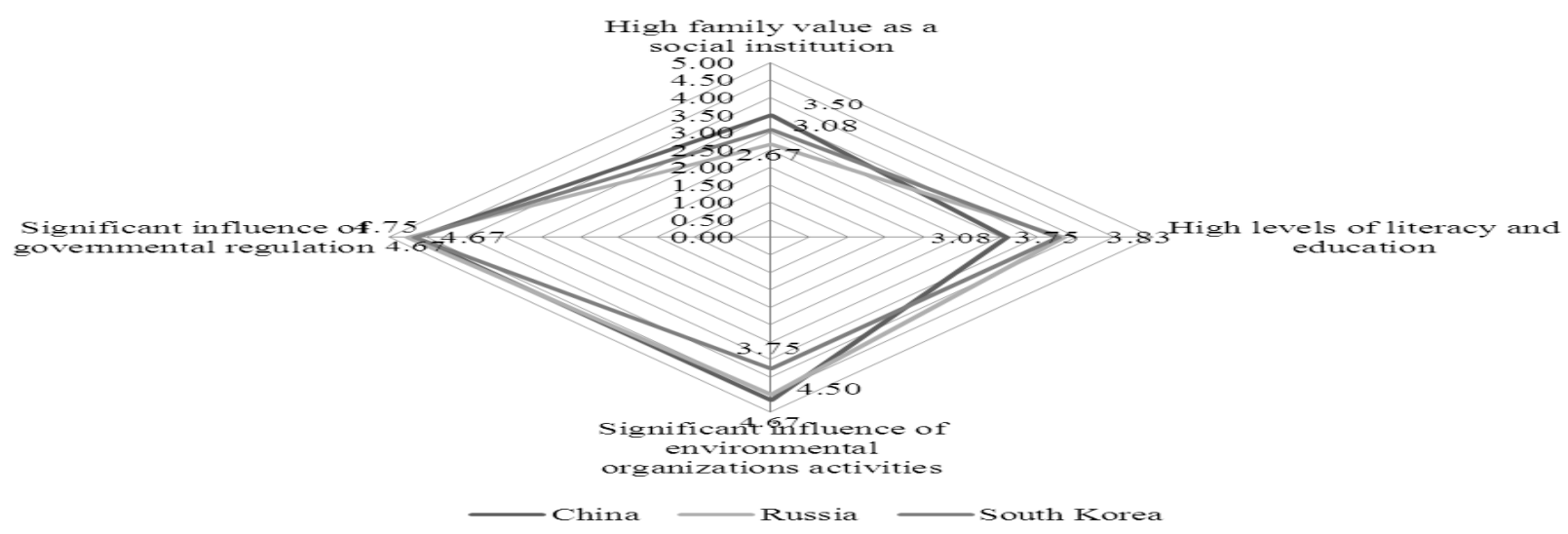

Figure 3. Comparison of conformity assessment of the institutional environment components with respect to cultures of the Asia-Pacific countries, 2014 (Author's development) 
Gaps are observed with respect to parameters, such as the level of scientific and technological development and the raw materials stock. Comparing these countries in terms of the material environment elements, we note that Russia is considerably behind China and South Korea in scientific and technological development and its potential, though vastly superiors in natural resources.

Differences in the assessment of the institutional environment are irrelevant.

3.2 Construction of the Compliance Matrices to Determine Concordance between Cultural Features and Fish and Seafood Consumption Patterns in the Selected Asia-Pacific Countries

Next were constructed compliance matrices to determine concordance between cultural features and fish and seafood consumption patterns in the concerned countries (Tables 2-7).

Table 2. Estimator matrix to assess the effect of cultural values on the fish and seafood consumption in China, 2014 (Author's development)

\begin{tabular}{|c|c|c|c|c|c|c|c|c|c|}
\hline $\begin{array}{l}\text { Cultural model } \\
\text { elements Consumer } \\
\text { behavior patterns }\end{array}$ & Cultural values & $\begin{array}{l}\text { Equality } \\
\text { of rights }\end{array}$ & Humanity & Youthfulness & $\begin{array}{l}\text { Social } \\
\text { conformity }\end{array}$ & Materialism & $\begin{array}{l}\text { Efficiency } \\
\text { and } \\
\text { pragmatism }\end{array}$ & $\begin{array}{l}\text { Proactive } \\
\text { attitude }\end{array}$ & $\begin{array}{l}\text { Power } \\
\text { over } \\
\text { nature }\end{array}$ \\
\hline $\begin{array}{l}\text { Selection of the } \\
\text { fish and seafood } \\
\text { type }\end{array}$ & 2.5 & 1.3 & 2.0 & 2.7 & 2.2 & 4.2 & 2.2 & 2.1 & 3.4 \\
\hline $\begin{array}{l}\text { Selection of } \\
\text { product } \\
\text { depending on } \\
\text { processing type }\end{array}$ & 1.3 & 1.3 & 1.3 & 3.5 & 1.3 & 3.2 & 2.2 & 1.8 & 2.1 \\
\hline $\begin{array}{l}\text { Fish and seafood } \\
\text { consumption } \\
\text { frequency }\end{array}$ & 2.3 & 1.8 & 1.3 & 4.5 & 3.8 & 3.7 & 2.0 & 2.3 & 2.3 \\
\hline $\begin{array}{l}\text { Amount of } \\
\text { one-time } \\
\text { purchase }\end{array}$ & 2.8 & 2.2 & 2.0 & 3.2 & 2.7 & 3.7 & 2.7 & 3.2 & 2.1 \\
\hline $\begin{array}{l}\text { Selection of the } \\
\text { point-of-purchase } \\
\text { location and } \\
\text { format }\end{array}$ & 3.5 & 3.2 & 2.7 & 2.3 & 3.8 & 4.7 & 3.0 & 3.4 & 2.2 \\
\hline $\begin{array}{l}\text { Trust to } \\
\text { advertising } \\
\text { communications }\end{array}$ & 3.8 & 3.5 & 3.2 & 3.2 & 4.7 & 4.7 & 3.5 & 2.2 & 1.5 \\
\hline
\end{tabular}

Selection of the fish and seafood type and the point-of-purchase location and format, as well as consumption frequency of Chinese consumers are pretty much influenced by materialism of national culture.

Table 3 presents an assessment of the effect of material and institutional environment elements on the fish and seafood consumption pattern in China.

Consumer behavior patterns in the fish and seafood market is greatly influenced by specification, such as country's level of economic development, because it is directly related to the living standards of the population.

The effect of the cultural values on the behavior of the Russian consumers significantly differs from the Chinese model of behavior (Table 4). This suggests essential cross-cultural differences between the two nations. 
Table 3. Estimator matrix to assess the effect of material and institutional environment elements on the fish and seafood consumption in China, 2014 (Author's development)

\begin{tabular}{|c|c|c|c|c|c|c|c|c|}
\hline \multirow{2}{*}{$\begin{array}{l}\begin{array}{l}\text { Cultural model } \\
\text { elements }\end{array} \\
\begin{array}{l}\text { Consumer behavior } \\
\text { patterns }\end{array}\end{array}$} & \multicolumn{3}{|c|}{ Material environment } & \multicolumn{5}{|c|}{ Institutional environment } \\
\hline & $\begin{array}{l}\text { Level of } \\
\text { scientific and } \\
\text { technological } \\
\text { development } \\
\text { and its } \\
\text { potential }\end{array}$ & $\begin{array}{l}\text { Level of } \\
\text { raw } \\
\text { materials } \\
\text { stock }\end{array}$ & $\begin{array}{l}\text { Geographical } \\
\text { location }\end{array}$ & $\begin{array}{l}\text { Level of } \\
\text { economic } \\
\text { development }\end{array}$ & $\begin{array}{l}\text { Family } \\
\text { value as a } \\
\text { social } \\
\text { institution }\end{array}$ & $\begin{array}{l}\text { Level of } \\
\text { literacy } \\
\text { and } \\
\text { education }\end{array}$ & $\begin{array}{l}\text { Environmental } \\
\text { organizations } \\
\text { activities }\end{array}$ & $\begin{array}{l}\text { Government } \\
\text { regulation }\end{array}$ \\
\hline $\begin{array}{l}\text { Selection of the } \\
\text { fish and seafood } \\
\text { type }\end{array}$ & 4.3 & 4.2 & 4.5 & 4.5 & 2.2 & 3.9 & 3.8 & 1.6 \\
\hline $\begin{array}{l}\text { Selection of } \\
\text { product } \\
\text { depending on } \\
\text { processing type }\end{array}$ & 4.7 & 2.1 & 3.1 & 3.3 & 3.2 & 4.0 & 3.8 & 1.2 \\
\hline $\begin{array}{l}\text { Fish and seafood } \\
\text { consumption } \\
\text { frequency }\end{array}$ & 3.2 & 4.3 & 4.6 & 4.7 & 2.6 & 2.0 & 2.7 & 2.1 \\
\hline $\begin{array}{l}\text { Amount of } \\
\text { one-time purchase }\end{array}$ & 2.3 & 4.3 & 4.3 & 4.5 & 3.8 & 2.3 & 2.1 & 1.2 \\
\hline $\begin{array}{l}\text { Selection of the } \\
\text { point-of-purchase } \\
\text { location and } \\
\text { format }\end{array}$ & 3.6 & 3.1 & 3.4 & 3.1 & 3.8 & 3.3 & 3.2 & 1.2 \\
\hline $\begin{array}{l}\text { Trust to } \\
\text { advertising } \\
\text { communications }\end{array}$ & 3.8 & 3.2 & 4.3 & 3.6 & 4.3 & 4.8 & 4.3 & 3.4 \\
\hline
\end{tabular}

Table 4. Estimator matrix to assess the effect of cultural values on the fish and seafood consumption patterns in China, 2014 (Author's development)

\begin{tabular}{|c|c|c|c|c|c|c|c|c|c|}
\hline $\begin{array}{l}\text { Cultural } \\
\text { elements }\end{array}$ & Cultural values & & & & & & & & \\
\hline $\begin{array}{l}\text { Consumer Behavior } \\
\text { patterns }\end{array}$ & Individualism & $\begin{array}{l}\text { Equality } \\
\text { of rights }\end{array}$ & Humanity & Youthfulness & $\begin{array}{l}\text { Social } \\
\text { conformism }\end{array}$ & Materialism & $\begin{array}{l}\text { Efficiency } \\
\text { and } \\
\text { pragmatism }\end{array}$ & $\begin{array}{l}\text { Proactive } \\
\text { attitude }\end{array}$ & $\begin{array}{l}\text { Power } \\
\text { over } \\
\text { nature }\end{array}$ \\
\hline $\begin{array}{l}\text { Selection of the } \\
\text { fish and seafood } \\
\text { type }\end{array}$ & 4.5 & 1.3 & 2.0 & 4.4 & 4.6 & 4.6 & 2.2 & 2.1 & 3.4 \\
\hline $\begin{array}{l}\text { Selection of } \\
\text { product } \\
\text { depending on } \\
\text { processing type }\end{array}$ & 3.4 & 1.3 & 1.3 & 4.8 & 3.2 & 4.2 & 2.2 & 1.8 & 2.1 \\
\hline $\begin{array}{l}\text { Fish and seafood } \\
\text { consumption } \\
\text { frequency }\end{array}$ & 4.4 & 1.8 & 1.3 & 4.5 & 4.5 & 4.5 & 2.0 & 2.3 & 2.3 \\
\hline $\begin{array}{l}\text { Amount } \\
\text { one-time } \\
\text { purchase }\end{array}$ & 3.2 & 2.2 & 1.7 & 2.1 & 2.3 & 4.0 & 2.7 & 3.2 & 2.1 \\
\hline $\begin{array}{l}\text { Selection of the } \\
\text { point-of-purchase } \\
\text { location and } \\
\text { format }\end{array}$ & 3.4 & 3.2 & 2.7 & 2.6 & 4.7 & 4.6 & 3.0 & 3.4 & 2.2 \\
\hline $\begin{array}{l}\text { Trust to } \\
\text { advertising } \\
\text { communications }\end{array}$ & 2.3 & 3.5 & 2.1 & 1.8 & 3.6 & 3.2 & 3.5 & 2.2 & 1.5 \\
\hline
\end{tabular}


Behavior of the Russian consumers in the fish and seafood market is determined to a large extent by cultural aspects, such as individualism, youthfulness, social conformity, and materialism.

Next we consider the effect of the material and institutional environment on the fish and seafood consumption patterns in Russia (Table 5).

Table 5. Estimator matrix to assess the effect of material and institutional environment elements on the fish and seafood consumption patterns in Russia, 2014 (Author's development)

\begin{tabular}{|c|c|c|c|c|c|c|c|c|}
\hline $\begin{array}{l}\text { Cultural } \\
\text { elements }\end{array}$ & Material enviro & ment & & & Institutional & nvironment & & \\
\hline $\begin{array}{l}\text { Consumer Behavior } \\
\text { patterns }\end{array}$ & $\begin{array}{l}\text { Level of } \\
\text { scientific and } \\
\text { technological } \\
\text { development } \\
\text { and its } \\
\text { potential }\end{array}$ & $\begin{array}{l}\text { Level of } \\
\text { raw } \\
\text { materials } \\
\text { stock }\end{array}$ & $\begin{array}{l}\text { Geographical } \\
\text { location }\end{array}$ & $\begin{array}{l}\text { Level of } \\
\text { economic } \\
\text { development }\end{array}$ & $\begin{array}{l}\text { Family } \\
\text { value as a } \\
\text { social } \\
\text { institution }\end{array}$ & $\begin{array}{l}\text { Level of } \\
\text { literacy } \\
\text { and } \\
\text { education }\end{array}$ & $\begin{array}{l}\text { Environmental } \\
\text { organizations } \\
\text { activities }\end{array}$ & $\begin{array}{l}\text { Government } \\
\text { regulation }\end{array}$ \\
\hline $\begin{array}{l}\text { Selection of the } \\
\text { fish and seafood } \\
\text { type }\end{array}$ & 4.4 & 3.1 & 4.5 & 4.5 & 3.5 & 3.4 & 2.8 & 4.5 \\
\hline $\begin{array}{l}\text { Selection of } \\
\text { product } \\
\text { depending on } \\
\text { processing type }\end{array}$ & 4.7 & 2.3 & 4.2 & 2.4 & 3.5 & 3.6 & 1.4 & 2.6 \\
\hline $\begin{array}{l}\text { Fish and seafood } \\
\text { consumption } \\
\text { frequency }\end{array}$ & 4.1 & 3.4 & 4.8 & 4.7 & 3.2 & 3.0 & 1.8 & 2.4 \\
\hline $\begin{array}{l}\text { Amount of } \\
\text { one-time purchase }\end{array}$ & 2.3 & 3.4 & 4.3 & 3.8 & 3.6 & 2.3 & 1.4 & 2.4 \\
\hline $\begin{array}{l}\text { Selection of the } \\
\text { point-of-purchase } \\
\text { location and } \\
\text { format }\end{array}$ & 3.2 & 2.4 & 4.4 & 2.6 & 2.2 & 2.4 & 2.8 & 1.8 \\
\hline $\begin{array}{l}\text { Trust to } \\
\text { advertising } \\
\text { communications }\end{array}$ & 3.8 & 3.4 & 4.3 & 3.6 & 4.6 & 4.8 & 2.3 & 3.8 \\
\hline
\end{tabular}

The effect of the material and institutional environment elements on the fish and seafood consumption patterns in Russia is practically similar to that in China.

Questionnaire survey showed that in South Korea the effect of cultural elements on the fish and seafood consumption is pretty much the same as that in China (Table 6).

Culture components, such as materialism, proactive attitude, efficiency and pragmatism have the greatest effect on the fish and seafood consumption in South Korea. One may notice that in all three countries under consideration, factors, such as humanism and equality of rights have practically no effect on consumer behavior.

Next we consider the effect of the material and institutional environment on the fish and seafood consumption patterns in South Korea (Table 7).

The effect of the material and institutional environment elements on the fish and seafood consumption in South Korea practically does not differ from the situation in China and Russia. 
Table 6. Estimator matrix to assess the effect of cultural values on the fish and seafood consumption patterns in South Korea, 2014 (Author's development)

\begin{tabular}{|c|c|c|c|c|c|c|c|c|c|}
\hline $\begin{array}{l}\text { Cultural } \quad \text { Model } \\
\text { elements }\end{array}$ & Cultural values & & & & & & & & \\
\hline $\begin{array}{l}\text { Consumer Behavior } \\
\text { patterns }\end{array}$ & Individualism & $\begin{array}{l}\text { Equality } \\
\text { of rights }\end{array}$ & Humanity & Youthfulness & $\begin{array}{l}\text { Social } \\
\text { conformism }\end{array}$ & Materialism & $\begin{array}{l}\text { Efficiency } \\
\text { and } \\
\text { pragmatism }\end{array}$ & $\begin{array}{l}\text { Proactive } \\
\text { attitude }\end{array}$ & $\begin{array}{l}\text { Power } \\
\text { over } \\
\text { nature }\end{array}$ \\
\hline $\begin{array}{l}\text { Selection of the } \\
\text { fish and seafood } \\
\text { type }\end{array}$ & 3.6 & 1.3 & 2.0 & 4.2 & 2.1 & 4.2 & 2.2 & 4.0 & 3.4 \\
\hline $\begin{array}{l}\text { Selection of } \\
\text { product } \\
\text { depending on } \\
\text { processing type }\end{array}$ & 1.3 & 1.3 & 1.3 & 3.5 & 1.3 & 3.2 & 4.6 & 4.4 & 2.1 \\
\hline $\begin{array}{l}\text { Fish and seafood } \\
\text { consumption } \\
\text { frequency }\end{array}$ & 3.5 & 1.8 & 1.3 & 4.5 & 4.4 & 3.7 & 2.3 & 2.3 & 2.3 \\
\hline $\begin{array}{l}\text { Amount of } \\
\text { one-time } \\
\text { purchase }\end{array}$ & 2.8 & 2.2 & 2.0 & 3.2 & 2.7 & 3.7 & 4.3 & 3.8 & 2.1 \\
\hline $\begin{array}{l}\text { Selection of the } \\
\text { point-of-purchase } \\
\text { location and } \\
\text { format }\end{array}$ & 4.0 & 3.2 & 2.7 & 2.3 & 3.8 & 4.7 & 4.6 & 4.1 & 2.2 \\
\hline $\begin{array}{l}\text { Trust to } \\
\text { advertising } \\
\text { communications }\end{array}$ & 3.8 & 3.5 & 3.2 & 2.0 & 3.5 & 4.7 & 3.5 & 2.2 & 1.5 \\
\hline
\end{tabular}

Table7. Estimator matrix to assess the effect of material and institutional environment elements on the fish and seafood consumption patterns in South Korea, 2014 (Author's development)

\begin{tabular}{|c|c|c|c|c|c|c|c|c|}
\hline $\begin{array}{ll}\text { Cultural } & \text { Model }\end{array}$ & Material enviror & ment & & & Institutiona & environment & & \\
\hline $\begin{array}{l}\text { Consumer Behavior } \\
\text { patterns }\end{array}$ & $\begin{array}{l}\text { Level of } \\
\text { scientific and } \\
\text { technological } \\
\text { development } \\
\text { and its } \\
\text { potential }\end{array}$ & $\begin{array}{l}\text { Level of } \\
\text { raw } \\
\text { materials } \\
\text { stock }\end{array}$ & $\begin{array}{l}\text { Geographical } \\
\text { location }\end{array}$ & $\begin{array}{l}\text { Level of } \\
\text { economic } \\
\text { development }\end{array}$ & $\begin{array}{l}\text { Family } \\
\text { value as a } \\
\text { social } \\
\text { institution }\end{array}$ & $\begin{array}{l}\text { Level of } \\
\text { literacy } \\
\text { and } \\
\text { education }\end{array}$ & $\begin{array}{l}\text { Environmental } \\
\text { organizations } \\
\text { activities }\end{array}$ & $\begin{array}{l}\text { Government } \\
\text { regulation }\end{array}$ \\
\hline $\begin{array}{l}\text { Selection of the } \\
\text { fish and seafood } \\
\text { type }\end{array}$ & 4.8 & 4.2 & 4.2 & 4.5 & 4.2 & 3.9 & 3.8 & 1.6 \\
\hline $\begin{array}{l}\text { Selection of } \\
\text { product } \\
\text { depending on } \\
\text { processing type }\end{array}$ & 4.8 & 3.4 & 2.8 & 3.8 & 3.2 & 3.5 & 3.8 & 1.2 \\
\hline $\begin{array}{l}\text { Fish and seafood } \\
\text { consumption } \\
\text { frequency }\end{array}$ & 3.4 & 4.3 & 4.6 & 4.8 & 2.6 & 4.0 & 2.7 & 1.6 \\
\hline $\begin{array}{l}\text { Amount of } \\
\text { one-time purchase }\end{array}$ & 2.3 & 4.3 & 4.3 & 4.5 & 3.8 & 2.3 & 2.1 & 1.2 \\
\hline $\begin{array}{l}\text { Selection of the } \\
\text { point-of-purchase } \\
\text { location and } \\
\text { format }\end{array}$ & 3.6 & 3.1 & 3.4 & 3.1 & 3.8 & 3.3 & 2.5 & 1.2 \\
\hline $\begin{array}{l}\text { Trust to } \\
\text { advertising } \\
\text { communications }\end{array}$ & 3.8 & 3.2 & 4.3 & 3.6 & 4.3 & 4.6 & 4.3 & 3.8 \\
\hline
\end{tabular}




\section{Discussion}

The need to consider in marketing solutions the value-conscious, material and institutional elements of the cultural model is obvious. In terms of studying cultural models, there is variety of methodologies and approaches that use both quantitative and qualitative techniques; each of them is unique and has its own peculiarities, advantages and weaknesses. Thus, the study of cross-cultural features involves methodologies, based on cultural values inventory (Aleshina, 2011; Moven, 1995), a description of the consumer psychological differences (Cheungetal, 2011); Rokeach technique, which is successfully used in practice (Blekuelletal, 2007); Allport method (Allport, 2002), which became popular in America since 1957. This method is based on a comparative study of the values of Japanese and American students, whereas in 1959 the method was applied to assess the values of Taiwanese, Japanese, Chinese and American students. Disadvantage of above approaches is that their separate use does not give a complete idea of the cultural model as a whole. Another problem is the choice of the comparison base for cross-cultural study of values. One more problem is related to the integrity and objectivity of the information received, as well as the large time, human, and material costs needed.

Thus, the indicated methods are used quite often, and most of the techniques of comparative cross-cultural studies are based on them. However, it should be noted that researchers have rarely used their combination or complex approaches, although perhaps, this could be the most fruitful approach in solving such a complex problem, as the consumer cross-cultural studies. The approach, proposed by authors, is comprehensive. It is based on marketing and allows one to eliminate a number of methodological problems. Development of further research in this area should be focused on the definition of marketing incentives, such as product attributes, price and sales characteristics, as well as marketing communications, with allowances made for the specific models of consumer behavior, developed on the basis of cross-cultural analysis.

\section{Conclusion}

In this study the following results were obtained.

1) A survey frame was developed to analyze the effect of cross-cultural differences in the behavior of the fish and seafood market consumers in selected countries of the Asia-Pacific region.

2) Formation and construction features of the cultural models were determined, including a specification of cultural values, as well as social (institutional) and the material environment elements, tailored to the fish and seafood market in the selected countries of the Asia-Pacific region. Differences in the Chinese, Russian and South Korean cultures were revealed within the framework of cross-cultural analysis. It was established that the Chinese culture model is characterized by cultural values, such as humanism, materialism, and equality of rights, i.e. equal rights to life and liberty. Material environment is characterized by a high degree of government influence on society. A distinctive feature of the Russian cultural model is individualism, i.e. human's desire to be independent and to rely only on himself, as well as such feature as youthfulness, i.e. the desire to appear young and act accordingly. Cultural model of South Korea is characterized by equality of rights of all society members and humanism. According to respondents, a distinctive feature of the nation is the effectiveness and pragmatism, i.e. desire to do everything in a best possible way, and even better. In addition, the culture of this country, unlike the previous two, is characterized by social conformity, i.e. obedience of people to social and group norms.

3) Methodological tools were proposed to assess the effect of cultural elements on the behavior of fish and seafood market consumers in selected Asia-Pacific countries (contingency matrix) that allowed one to determine the cross-cultural gaps in consumer behavior in different countries. This must be taken into account, when developing company strategies of entering the international markets in order to enhance their competitiveness. Analysis of the estimator matrices in order to assess the effect of the cultural elements on the behavior of fish and seafood market consumers in the Asia-Pacific countries showed that in general the effect of cultural elements is uneven and is manifested through the consumer reactions towards advertising communications, as well as consumer preferences in terms the point-of-purchase location and format. It should be noted that government regulation of the fishing industry enterprises and the activities of international environmental organizations is an important part of the culture of all the countries surveyed, and has a significant effect on the consumer behavior in the market under study.

\section{Reference}

Agarwal, J., Malhotra, K., Naresh, B., \& Ruth, N. (2010). A Cross-National and Cross-Cultural Approach to Global Market Segmentation: An Application Using Consumers' Perceived Service Quality. Journal of International Marketing, 18(3), 18-40. http://dx.doi.org/10.1509/jimk.18.3.18 
Aleshina, I. (2010). Open innovation: A cross-cultural factors in the context of globalization. Innovations, 7 , $30-35$.

Aleshina, I. (2011). Marketing: Cross-cultural challenges and opportunities. Contemporary management: Problems, hypotheses, and study. Part 2. Moscow: Higher School of Economics.

Allport, G. (2002). The formation of personality. Selected works. Translated from English. M.: Smisl.

Berry, D., Purtinga, A., Segall, M., \& Dasen, P. (2007). Cross-Cultural Psychology. Translated from English. Kharkiv: Humanitarian Center.

Blackwell, \& Roger. (2007). Consumer behavior. St. Peter.

Cheung, F., Van de Vijver, F., \& Leong, F. (2011). Toward a new approach to the assessment of personality in culture. American Psychologist, 66(7), 593-603. http://dx.doi.org/10.1037/a0022389

Dimitrova, R., Bender, M., \& Van de Vijver, F. (2014). Global perspectives on well-being in immigrant families. New York, NY: Springer. http://dx.doi.org/10.1007/978-1-4614-9129-3

Gelade, G. (2008). IQ, cultural values, and the technological achievement of nations. Intelligence, 36(6), 711-718. http://dx.doi.org/10.1016/j.intell.2008.04.003

Gesteland, R. (2012). Cross Cultural Business Behavior: Negotiating, Selling, Sourcing and Managing across Cultures. Copenhagen: Business School Press.

Harrison, L. (2006). The Central Liberal Truth: How Politics Can Change a Culture and Save it from itself. Oxford University Press.

Hofstede, G., Pedersen, P., \& Hofstede, G. (2002). Exploring Culture: Exercises, Stories and Synthetic Cultures. Yarmouth, Maine: Intercultural Press.

Kuznetsova, E., \& Leontiev, D. (2012). Personal values: The concept, classification and approaches. OSU Herald, 10(116). Retrieved July 25, 2014, from http://www.vestnik.osu.ru/2010_10/3.pdf

Lebedeva, N. (2010). Effect of cultural values on the assessment of the social and economic behavior situations. Almanac on contemporary science and education, 10(41), 104-106.

Malda, M., Van de Vijver, F., \& Temane, M. (2010). Rugby versus soccer in South Africa: Content familiarity explains most cross-cultural differences in cognitive test scores. Intelligence, 38, 582-595. http://dx.doi.org/ 10.1016/j.intell.2010.07.004

Matsumoto, D. (2002). Psychology and Culture. St. Petersburg- Moscow: Evroznak.

Moven, J. (1995). Consumer Behavior (4th ed.). Macmillan Publishing Co.

Owe, E., Vignoles, V., Becker, M., Brown, R., Smith, P., Lee, S., \& Tatarko, A. (2013). Conceptualism as an important facet of individualism-collectivism: personhood beliefs across 37 national groups. Journal of Cross-Cultural Psychology, 44(1), 24-45. http://dx.doi.org/10.1177/0022022111430255

Rigby, D., Gruver, K., \& Allen, J. (2009). Innovations in Turbulent Times. Harvard Business Review.

Romanova, I., \& Noskova, E. (2014). A methodology to study the effect of cross-cultural differences on consumer behavior in the B2B market. Life Science Journal, 11, 655-659.

Tatarko, A. (2012). Individual values, social and psychological capital: Cross-cultural analysis. Psychology. Journal of the Higher School of Economics, 2, 71-88.

\section{Copyrights}

Copyright for this article is retained by the author(s), with first publication rights granted to the journal.

This is an open-access article distributed under the terms and conditions of the Creative Commons Attribution license (http://creativecommons.org/licenses/by/3.0/). 